\title{
Christus medicus - Christus patiens: Healing as exorcism in context
}

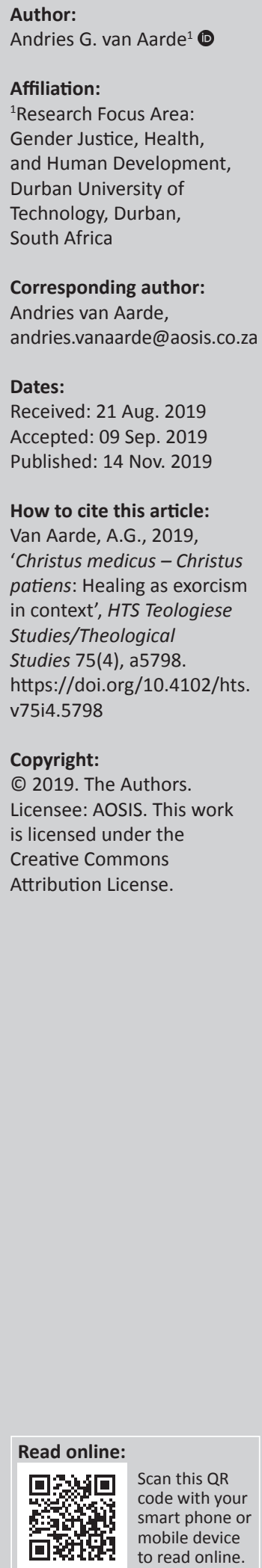

The aim of this article is to argue that healing stories in the Jesus tradition should be understood as exorcisms, even if the concept of demonisation does not occur in the narrative. In the theistic and mythological context of the 1st-century Graeco-Roman religious and political world, external forces responsible for social imbalances pertain to the demonisation of body and spirit. Medical cure was also embedded in the same biopolitical setting. The article describes aspects of this biopolitics and the role of ancient physicians. However, Jesus' revolutionary acts were not deeds of a medical doctor, but ought to be understood as the healing activity of a faith healer who empowered traumatised people by creating safe space for them within a quasi-fictive kinship network. The article concludes with an application of the dialectic notion 'Christus medicus - Christus patiens' in the life of the present-day network of Jesus-followers.

Keywords: Jesus tradition; healing; exorcism; physicians in antiquity; imperialism; marginalisation; fictive family.

\section{Biopolitics}

The healings of Jesus brought about a paradigm shift. Those who were healed by Jesus were people who had been traumatised by the 'biopolitics' of the time. Imperial exploitation and religious codes that rendered people impure, and therefore unacceptable before God, led to intrafamilial conflict. The result of this was trauma and demonisation, ascribing adversity to external forces, called demons. People lost their land, their subsistence. If they succumbed to disease, they were cast out of households and communities. In that context, healing (of trauma) and exorcism (of demons) were two sides of the same coin. Jesus, the revolutionary healer, was an exorcist.

Through his healings people were again accepted into spaces of fellowship. Jesus created a fictive kinship (cf. Hellerman 2001:4, 8, 84), the family of God, where everyone could be a child of God, where everyone could belong.

However, among the early Jesus-followers there were two movements that attached religious significance to biopolitics. For the gnostic-minded group, the divine element in human beings should be freed from the body and the cosmos in order to be united with the divine (cf. Roukema 1998:13). For the Ebionites, on the other hand, the presence of God could only be experienced in the biological family (cf. Cook 2013:17). The biological family of Jesus was central to them and legends of this family abound in their writings and reception of history of their documents. Both groups disappeared: the Ebionites (as one group among the multifaceted 'Jewish-Christian' movements during the first three centuries after the execution of Jesus) mainly because of Roman persecution (cf. Horrell 2000:138-139, 264) and the 'Gnostics' mainly because of creedal Christianity's intolerance (cf., inter alia, McGrath 2017:123). However, 'New Testament Christianity' prevails.

With the rise of nationalism during the 19th century (cf. Horne 2004:23; Moxnes 2011:10), Christians forgot the $\tilde{\eta} \theta$ os of Jesus. In the $\beta \alpha \sigma i \lambda \varepsilon i ́ \alpha$ ethics of Jesus, the biological family does not constitute who are counted to be God's family. However, this changed over time. Because of the

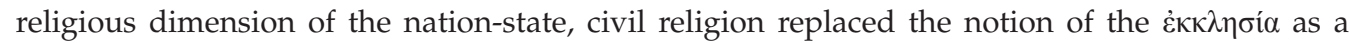

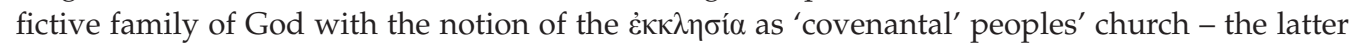
constituted as a biological and national entity without an emphasis on the $\chi \alpha \rho i \sigma \mu \alpha \tau \alpha$ that Paul had in mind in his letters to the Corinthians (chapter 12) and Romans (chapter 12).

The 'biopolitics' of the main streams of Jesus-followers in earliest Christianity can be described as an ellipse. When one stretches the point on the right beyond breakpoint, Jesus-fellowship becomes 
a secular phenomenon deprived of a spirituality that attests to transcendental experience that does not aim to maintain the biological family of Jesus of Nazareth as an essential soteriological entity. When one stretches the point on the left beyond breakpoint, Jesus-fellowship evaporates almost as an anti-humanness uprooted from earthly existence. This would happen when one follows 'Gnosticism' to its extreme and ends up with a disdain in materiality and cosmic realities. Such an extremity generates 'hatred' of the biological family.

When the Sayings Source Q 14:26 (and the Gospel of Thomas $55: 1-2 a ; 101)$ says that Jesus demands his followers to 'hate' their own father and mother, wife and children, and brothers and sisters, it seems to sound almost as if the voice of Jesus embraced such sarcophobic biopolitics (cf. Crossan 1999:xxiii; see Farley 2007:14 on the historical Jesus). The 'memory register' (cf. Garner 2011:677-724; Kirk 2016:3-4) of people who 'heard that he has come home' (Mk 2:1) when Jesus came to stay with Peter and Andrew in their family residence in Capernaum (Mk 1:29-34; 2:1-12) contradicts such a disposition. Here in Capernaum, in the midst of the biological family (cf. Dube 2018a:3), Jesus healed Peter's mother-in-law, many demon-possessed sick and a paralysed man. Another example from this 'memory register' (Mk 2:11) in the Jesus tradition is his merciful words addressed to those who were traumatised by demons such as the paralysed man whom

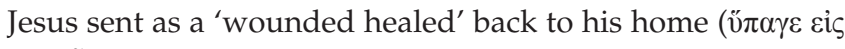

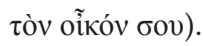

Jesus was quite clear about his view (Mk 3:34) that the people

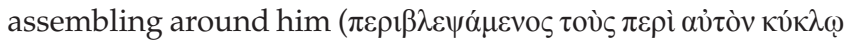
$\kappa \alpha \theta \eta \mu \varepsilon ́ v o v \varsigma)$ - people who definitely were not his biological family - constituted a fictive family of God (Mk 3:35), because

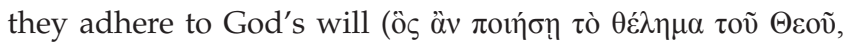

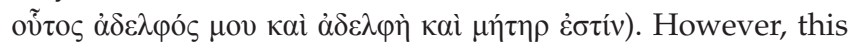
does not diminish his compassion for the Canaanite (SyroPhoenician) mother (Mk 7:24-30 / / Mt 15:21-23) of a 'demon-

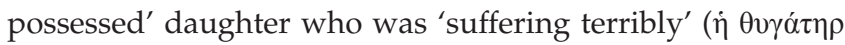

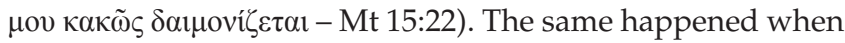
Jesus healed the slave of a Roman military officer (a commander of a century - see later) who was sick to death (Mt 8:5-13 // Lk 7:1-10). In John's gospel, the traumatised man (a particular Herodian official - $\tau ı \varsigma \beta \alpha \sigma \lambda \lambda \iota k o ̀ s)$ is a father

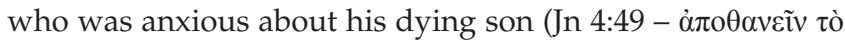

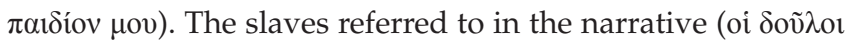
- Jn 4:51) were members of the household (i் oíkí $\alpha$ v̉ंoṽ ö $\lambda \eta$ - Jn 4:53) of the $\beta \alpha \sigma i \lambda \iota \kappa o ̀ s$, similarly than the dying slave of the military officer in the parallel Synoptic pericopes.

Inferred from these memorised stories, it is clear that Jesus' distinctive biopolitics did not aim at the biological family as indifferent and he did not revolutionise familial relationships in the extreme sense of the word (cf. Borg 2006:129-130). Yet,

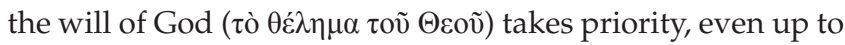
the point where Jesus demands from his followers a 'hatred' of familial values. This demand aims at the embracing of the values of the family of God as 'fictive kin', that is, Jesus' 'kingdom ethics'. Thus, Jesus remains integral to the sociological structures of his Mediterranean context (cf. Legrand 2000:111-112).

In the time of formative Christianity, the structure of Mediterranean society consisted mainly of the following institutions: family as the highest priority, politics, economy and religion. In the Mediterranean world, religious, familial, political and economic structures cannot simply be divided into separate compartments. Family structures enjoyed the highest priority within which politics, economy and religion were embedded. A person's family not only determined his or her status within the community but also served as the primary economic, religious, educational and social network. Breaking of familial bonds also meant loss of these important networks (Malina \& Rohrbaugh 1992:100-101). The fact that religion was not a clearly demarcated terrain independent of, for instance, the medical terrain is to be inferred from the fact that it was a common practice to approach prophets and faith healers for healing (2 Ki 5:1-3). Jesus was such a 'faith healer', comparable with the ancient tradition of shamanic healing (cf. Craffert 2008:159; Dube 2018b:4; Walsh 2007:207-210).

\section{Doctors in antiquity}

This does not mean that there were no doctors in antiquity who were interested in the curing of the biomedical causes of biological defects. In the time after the Greek physicians Hippocrates (460-370 BCE), Asclepiades of Bithynia (124-40 BCE) and Aelius (Claudius) Galenus (Galen) (129-210 CE) (see Burnham 1999:254), medicine consisted of a tripartite system, namely, dietics, pharmacology and surgery (Jackson 1988:32). Asclepiades advocated 'the equal treatment of women because most diseases are common to both genders' (Yapijakis 2009:511). He is known for his humane treatment of patients, based on the motive of $\varphi \imath \lambda i \alpha$ [friendship or friendly love]. He also divided diseases into acute and chronic ones and favoured 'mild therapeutic methods such as health diet, exposure to light, hydrotherapy, massage, physical exercise' together with employment of 'herbal remedies and surgery' where needed (Yapijakis 2009:511). He treated persons with mental disorders by also using music therapy. His compassion for his patients is expressed with the dictum '[f]or where there is love of human, there is also love of the art' (Yapijakis 2009:511).

According to the Hippocratic Corpus (see Craik 2014) on anatomy and its dependence on physiology, pathology and surgery - the 'cornerstone of modern medicine' (Jackson 1988):

$[N]$ one of the internal organs was properly understood, and although there was some notion of the vascular system and pulse, the function of the heart as a pump and the circulation of blood were completely unknown, as was too, the mechanism of breathing. (p. 22)

According to the Hippocratic Corpus, two theories characterise Greek medicine, namely, that of the four humours and that of the pneuma. The first are essential elements in bodily metabolism (e.g. blood, phlegm/mucus, 
especially that of the nose; yellow bile and black bile or excreted or vomited blood from internal haemorrhage). Blood and phlegm are the metabolic agents of the wet elements that are air and water, respectively. The last two 'humours' (i.e. yellow bile and black bile) are the metabolic agents of the dry elements, which are fire and earth, respectively (see Jouanna 2012:335-360). The pneuma 'was seen as the source of consciousness in thought, perception and sensation' (Jackson 1988: 22). However, it is unclear whether these two theories influenced Paul's body-soul

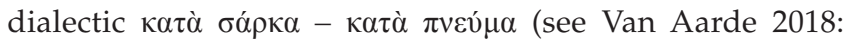
359-375).

Historical writing of medicine in the Graeco-Roman world mentions - only to refer to a few among many - Thessalus of Tralles (c. 70-95 CE) (see Bartlett \& Stempsey 2005:223), as the famous Roman physician and court physician of Emperor Nero. Soranus of Ephesus (see Drabkin 1951:503-518) was a native of Ephesus, known for his four-volume treatise on gynaecology, who practised medicine at Alexandria and Rome during the reigns of the emperors Trajan and Hadrian (98-138 CE) and died before Galen wrote his work De Methodo Medendi in c. 178 CE (see Todman 2008). Leonidas of Alexandria, a surgeon who lived in the 2 nd and 3 rd centuries, provided the first detailed description of a mastectomy (quoted by Paulos of Aegina [625-690 CE] in his Medical Compendium in Seven Books; see Pormann 2008:629). Augustine of Hippo (354-430 CE) coined the term Christus medicus with reference to Christians who healed people bodily and spiritually after the model of Jesus himself (see Arbesmann (1954) 2016:1-28; Gollwitzer-Voll [2007] 2019:245-299).

However, Jesus of Nazareth is not to be found among these physicians in antiquity. Smith (1978), in his book entitled Jesus the Magician, is much closer to a plausible contextualisation:

After undergoing a baptism believed to purge him of sin, Jesus experienced the descent of a spirit upon him - the experience that made a man a magician - and heard himself declared a god, as magicians claimed to be. Then 'the spirit drove him out into the desert', a common shamanic phenomenon. After visionary experiences there, he returned to Galilee where his new spiritual power manifested itself in exorcism, in cures of types familiar in magic, in teaching, with magical parallels and authority, and in the call of disciples, who, like persons enchanted, were constrained to leave their families and belongings and follow him alone. (pp. 137-138)

During the Graeco-Roman period physicians were often influenced by their belief in magic and external evil forces. The so-called 'folk medicine' features in Celsus' view on dietics, preventive medicine and the treatment of diseases. The notion 'metempsychosis', used by Pythagoras of Samos (c. 570 BCE-c. 495 BCE) (see Kahn 2001:11, 24-25), expresses the belief that the 'soul was a fallen divinity, trapped in the body and condemned to a cycle of reincarnation from which it could only escape by means of physical and spiritual purity' (Jackson 1988:17). It seems that the 'theory of the humours' and the 'theory of the pneuma' had no influence in the biblical narratives about the healings done by Jesus of Nazareth (see Pilch 1988:60-66, 1995:314-337). On the contrary, the Toledoth Yeshu traditions in the Babylonian Talmud accuse Jesus as a performer of magic rituals (Bohak 2008:76). Celsus accused Jesus that 'it was by magic that he was able to do the miracles which he appeared to have performed' (see Origen, Contra Celsum 1.6, 38, 68) (see Callagher 1982). Such a view is also found in the gospel narratives. Jesus'

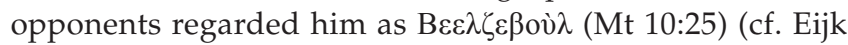
1999a:272, described in his De medicina [Liber I-VIII, as well as in Pliny's [Gaius Plinius Secundus] medical writings in his Historia naturalis [books XX-XXIX]; Bostock 1855; cf. also Jackson 1988:9; Whalley 1982:40).

Beelsebul (Baäl-Sebub) refers to the 'chief devil'. In the Hebrew Scriptures, Baäl-Sebub [Lord-of-the heights] also appears in a context of healing, but a healing performance not according to convention, in terms of the way Yahweh would prefer. 2 Kings 1:1-8 narrates the story of the Israelite king Ahaziah who had fallen through the lattice of his upper room and injured himself so badly that he became ill. However, he put his trust in Yahweh but rather wanted the foreign god of Ekron, Baäl-Zebub, to heal him. The prophet Elijah, inspired by an angel, strongly criticised the king (2 Ki 1):

'Is it because there is no God in Israel that you are going off to consult Baäl-Sebub, the god of Ekron?' Therefore this is what the Lord says: 'You will not leave the bed you are lying on. You will certainly die!' (vv. 3-4)

In Pharisaic context, Baäl-Sebub (Beelsebul) became the embodiment of the leader of the demonic forces who is the antagonist of God. The accusation appears in the context of Jesus' exorcisms, that is, the healings of Jesus, agent of God's 'holy spirit' who empowered his followers to resist evil but being imitators of agents who, when they speak, are

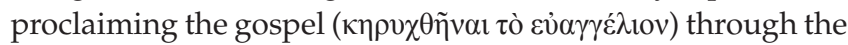

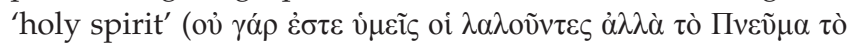
'A $\gamma$ lov - Mk 13:11).

\section{Healing as exorcism}

Empowerment through exorcism (healing) meant that Jesus and the Jesus-followers created an environment where the fictive 'family of God' replaced the 'biological family' and contributed to the solution of intrafamilial conflict. In the gospel tradition, references to intrafamilial conflict often yield to Jesus' exorcism. Whether explicitly mentioned or not, Jesus' healings imply the liberation of traumatised people characterised with psychosomatic illnesses, from demon possession. The background of the above-mentioned stigmatisation that Jesus is the agent of Baäl-Sebub is also his healing activities. His healings were not intended to be magic and it seems that it was also not be understood as magic by the contemporaries surrounding him, regardless of the defamation of Greek philosopher Celsus that Jesus is a magician whose miracles should be seen as deeds of sorcery

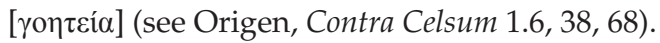


The traumatised that were healed experienced intrafamilial conflict. Such an element is to be seen in Mark's gospel (Mk 12:12): ' $[b]$ rother will betray brother to death and a father his child. Children will rebel against their parents and have them put to death'. In such a paradigm, if somebody was sick, an external force would have had an effect on that person. In Israel this would have meant it was accepted that God had allowed evil to possess the life of a person who was ill.

Such a person could therefore be viewed as an agent of evil and it could, within this society, be accepted that such a person would under certain circumstances be excluded by his or her family.

The biggest distress at the time was experienced in being found to be unacceptable, rejected by one's 'family of procreation' (the biological extended family) and the 'family of orientation' (Israel as $\dot{\varepsilon} \theta v o \varsigma)$. The 'wild man' from Gerasa is an example.

Carter (2015) provides a concise yet detailed reflection on the scholarly opinions regarding the demon-possessed 'Legion of Gerasa'. According to Goldsworthy (2003:95), the legion (in Greek, $\lambda \varepsilon \gamma \varepsilon \omega ́ v$ and in Latin legio, derived from the verb legō meaning 'to gather') constituted the Roman military elite during the Roman Imperial period. These imperial militarists were recruited exclusively from among Roman citizens. A legion was consisted of 10 cohorts of about 500 men each - a mighty force of 5000 or more. A cohort was commanded by

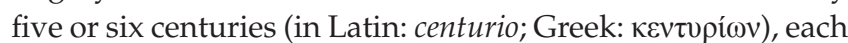
in command of approximately 100 legionaries.

The place where the 'demon-possessed wild man' (Carter 2015:143) confronts Jesus, namely, the region of the Gerasenes, is of special significance. The name of the region is derived from the Hebrew word שִָר, meaning to 'drive out' or to 'cast out'. The reading 'on the other side of the sea [of Galilee] in

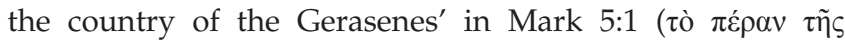

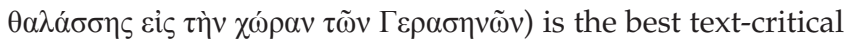
reading according to the main witnesses of the Alexandrian textual family, Codex Sinaiticus and Codex Vaticanus (see Carter 2015:143 n17). In the memory of the people of the land, 'Gerasenes' would remind of the town 'Gerasa'. According to Moore (2006:28), the region of the Gerasenes signifies 'the land in need of exorcism'. Carter (2015:143-144) describes Leander's (2013:212-215) depiction of 'military associations with Gerasa'. Flavius Josephus provides information as to why Gerasa was associated with militarianism. General Vespasian sent Lucius Annius to attack Gerasa during the Jewish war in 66-70 CE. This is why Gerasa was associated 'with a vicious and murderous assertion of Rome's military power' (Josephus, De Bello Judaico 4.487-489). Josephus narrates that about 1000 men were killed, Gerasa was ransacked, and families were taken captive, houses were burnt down and villages nearby were attacked.

Carter (2015:144) concludes, 'Jesus' interactions in this place with forces designated by the military term Legion create an important contestive and imitative intertextuality with
Roman military ... power'. Classisist Maud W. Gleason (2001:52) calls this 'metaphors of the body politic' in her 'biopolitical' reflection on Josephus. The ending of this exorcism story forms part of these metaphors: Jesus, at Legion's request, cast out the demons of the 'wild man', Legion, into a herd of pigs, 'about two thousand in number' (Mk 5:13). The implication of this element in the story is that the 'demon continues the destructive behavior' (Carter 2015:146). Carter (2015) comments:

The display and subjugation of wild and exotic animals in the arena communicated the same message of Rome's control over land and living creatures. Even the procurement of beasts for the arena demonstrated Rome's military control and the subjugation of the natural world. (p. 148)

The 'challenge-riposte' in the story of 'Legion of Gerasa' is similar to the 'challenge-riposte' in the narration about the defamation of Jesus as Baäl-Zebub/Beelsebul (Mt 10:25). It is about two 'powers'. In the Legion story, Jesus is depicted as the healer who takes the place of the emperor, the son of Zeus. In the defamation story, he is depicted as the 'son of the Most High God' (Mk 5:7). In Matthew's story where Jesus is accused of being an agent of Baäl-Zebub, the significance of his empowering and liberating exorcism is proclaimed from the rooftops. The story is no longer confined to the group of Jesus-followers. It is to be told and retold out in the open

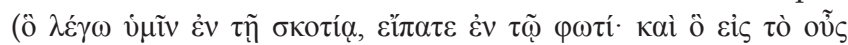

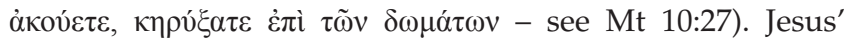
words are powerful and should be heard by all who have been traumatised by the powers that be (Mt 10):

Do not be afraid of those who kill the body but cannot kill the soul. Rather, be afraid of the One who can destroy both soul and body in hell ... Whoever acknowledges me before others, I will also acknowledge before my Father in heaven. But whoever disowns me before others, I will disown before my Father in heaven. Do not suppose that I have come to bring peace to the earth. I did not come to bring peace, but a sword. (vv. 28, 31-34)

This Jesus-logion in Matthew 10:34, 'I did not come to bring peace, but the sword', does not contradict Matthew's ethics of justice as expressed in the macarism about 'peacemakers' in Matthew 6:9.

Peacemakers - those who do not capitulate and join the Pharisaic collaboration with Roman imperial power - will be affected by intrafamilial conflict and maybe even by the sword. That could include persecution and finally crucifixion. Though wounded in this way, they are healed from the illness of having been possessed by the demonic imperial power of Rome. They are ensured of 'consolation' (by the macarism) because they have become 'children of God' (Mt 6:9),

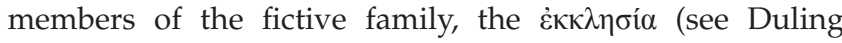
1999:17).

\section{Healing as empowerment}

Mark 13 (especially 13:12) is the main source for Matthew 10, including the reference to intrafamilial conflict. In the exorcism story of 'Legion of Gerasa' in Mark 5, Jesus heals 
traumatised people who were victims of imperial exploitation and family distortion. Their healing and liberation from the mighty one with its power over the subordinate 'human body' and over land and sea was accomplished when the herd of pigs 'rushed down the steep bank into the lake and were drowned' (Mk 5:13b). The pigs became the next vehicle for the demons and the impure spirits that had possessed the wild man Legion. This exorcism story anticipates about the life-giving significance of Jesus who would be crucified by "the powers that be," both the Roman Empire and the Jerusalem leadership. In the context of that time, demons were viewed as the antithesis of God. Liberation from demons would bring relief to the stress a person was enduring.

The deeds of the liberating Jesus can today, in the context of modern society, be defined as empowerment healings. Jesus 'empowered' people who succumbed to stress and enabled them to survive. He brought a renewed sense of meaning to people's lives. Jesus' healings were not miracles in the sense of supernatural interventions in the physical world. They signified God's engagement with the social world and lives of people. A miracle is not God's periodic interference with a closed natural order. It is, rather, the permanently hidden, uninterrupted heartbeat of the natural. It is present for those with the eyes and ears of faith.

The mercy (Latin: misericordia) of Jesus towards the les misérables is an emotional affect. It is expressed by word and deed. It is the opposite of a so-called 'misery gut', the English expression that describes someone who is never happy and complains a great deal. In Matthew 15:1, the Pharisaic scribes

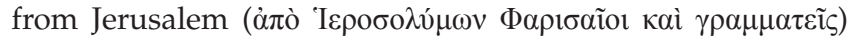

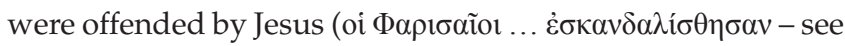
Mt 15:12). From their hearts came evil thoughts, Jesus said ( $\dot{\varepsilon} \kappa$

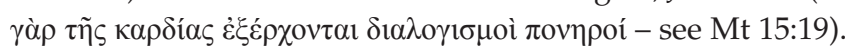
They were 'misery guts'. Jesus called them 'blind guides'

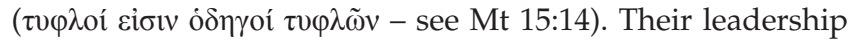
was misleading the crowds, les misérables and opened up the dreadful possibility that the crowd could reject the shepherd Jesus, 'who is called the Messiah' (Mt 27:22). This indeed became the dreadful reality when Jesus trial ended in oligarchy - the Jerusalem leadership leading the cries of 'crucify him!' (Mt 27:22, 23) and Pilate, the Roman hègemốn

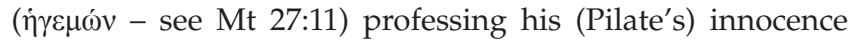

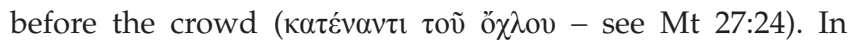
answer, the crowd ('all the people'; in Greek: $\pi \tilde{\alpha} \varsigma$ ó $\lambda \alpha$ ò $\varsigma$ - see Mt 27:25) responded, 'his blood is on us and on our children!'

The kind of 'misery guts' displayed by the temple authorities in Matthew is found again in 1 John 3:17 by one who sees a brother or sister in need but refuses to show compassion. The idiomatic expression is 'to close your bowels', 'to close your

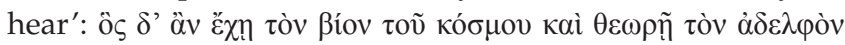

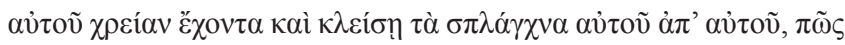

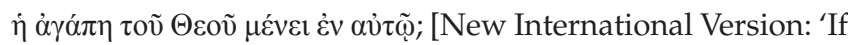
anyone has material possessions and sees a brother or sister in need but has no pity on them, how can the love of God be in that person? - see Nida \& Louw 1988:295]. In 2 Corinthians
6:12, Paul describes it as 'being restricted in the bowels'

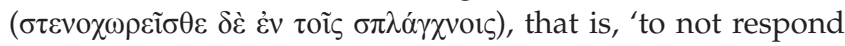
with affection to someone'. In 2 Corinthians 6 (NEV), Paul writes:

We have spoken freely to you, Corinthians, and opened wide our hearts to you. We are not withholding our affection from you, but you are withholding yours from us. As a fair exchange - I speak as to my children - open wide your hearts also. (vv. 11-13)

Long before Paul and the author of 1 John, the historical Jesus already said that the crowd were like sheep without a shepherd. They were blind and guided by blind leaders. That is why both they and their leaders would fall into a pit $(\mathrm{Mt}$ 15:14). Jesus' innards/bowels ( $\sigma \pi \lambda \alpha \dot{\gamma} \gamma \chi v \alpha)$ were filled with

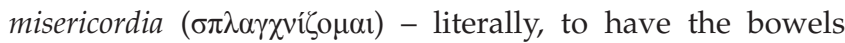

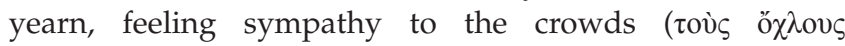
$\dot{\varepsilon} \sigma \pi \lambda \alpha \gamma \chi v i ́ \sigma \theta \eta \pi \varepsilon \rho \grave{l} \alpha \hat{\tau} \tilde{\omega} v$ - see Mt 9:36). These crowds were characterised in Matthew 15: 30 as 'the lame, the blind, the crippled, and the mute'.

The Matthean Jesus uses the 'sign of Jonah' in his controversy with the Pharisaic scribes (Mt 12:38) to compare the 'social

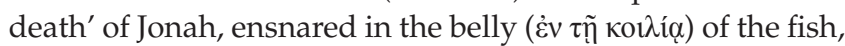
with his own confinement in the 'heart of the earth' ( $\dot{\varepsilon} v \tau \tilde{n}$

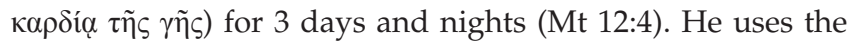
metaphor of 'social death' again when he opens his heart to

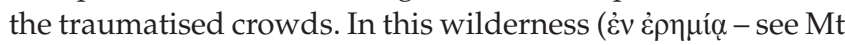

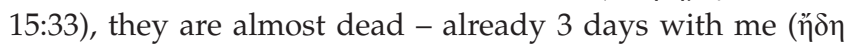

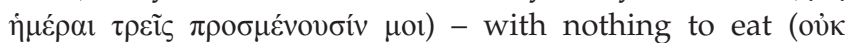

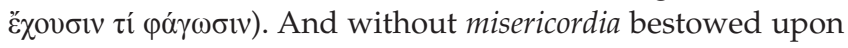
them, they certainly are bound to collapse on the way (Mt 15:32). Jonah's 'resurrection' after 3 days in the belly of the fish is surpassed by the resurrection of the son of man after 3 days in the 'heart of the earth' (Mt 12:40). Matthew emphasises: 'something (Jesus) greater than Jonah is here'

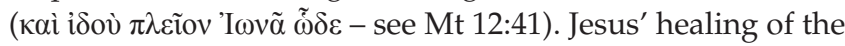
traumatised and his giving life (feeding) to those who suffer 'social death' is compassion. It adheres to the imperative: give them bread.

Something reminiscent is found in Paul's letter to the Philippians where he refers to the 'tenderness and

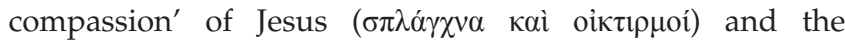
possibility that the Christ-followers can share in the 'comfort of his love' ( $\pi \alpha \rho \alpha \mu v ́ \theta 10 v$ a $\gamma \alpha \dot{\pi} \eta \uparrow)$ - both in the sense of receiving Jesus love and giving it to others as Jesus did (Phlp 2):

Therefore if you have any encouragement from being united with Christ, if any comfort from his love, if any common sharing in the Spirit, if any tenderness and compassion, then make my joy complete by being like-minded, having the same love, being one in spirit and of one mind. Do nothing out of selfish ambition or vain conceit. Rather, in humility value others above yourselves, not looking to your own interests but each of you to the interests of the others. In your relationships with one another, have the same mind-set as Christ Jesus. (vv. 1-5)

With regard to the Jesus tradition, healing can be seen as the act of an exorcist who orders the hostile entity or entities to leave the possessed person. An exorcist could make use of magic consisting of spells and witchcraft. Jesus' healings and 
exorcisms should be understood against the background of the 1st-century Mediterranean worldview. People believed that they shared their living space and environment with invisible spirits and demons. Several New Testament texts refer to this phenomenon: 1 Corinthians 10:20-21, 12:10; 2 Corinthians 4:4; Ephesians 1:21, 2:2; 6:12, 6.

Belief in the existence of invisible, hostile entities is presumed and so also the possibility to become possessed by such an entity. The possession could be permanent, occur intermittently or be a temporary condition. When demons were exorcised, the anxious possessed person would believe that the cause of the problem had disappeared. This belief would be confirmed by the healer and the social circle of the possessed person. The behaviour of the possessed person would change from anxiety to tranquility. What would have changed? The initial problems that caused the anxiety could still be present. However, the exorcism had changed the person's perception of these problems (Pilch 1995:330).

When reading about miracle healings, one should also bear in mind the competitive milieu in which the gospels originated. External forces were in competition with one another. The crowd participated in this intense competition. The controversies between Jesus and the Pharisees in the healing pericopes drew the crowds. For them Jesus had greater authority than the Pharisees (see Mt 7:28-29). In such a competitive milieu, the propaganda motive should be borne in mind. Apart from Jesus, there were many other miracle workers. The miracle workers were played off against one another. The evangelists placed Jesus at a level higher than the others (cf. Vermes 1973:58-82). In the various types of miracle narrative that were added to the Christian repertoire, Jesus was placed in competition with other charismatic wisdom teachers, exorcists and miracle workers (see Funk 1996:253).

In a world in which other miracle workers were also active it was important for the followers of Jesus to propagate Jesus as the miracle worker. Miracle traditions were used by the early Jesus groups in sermons, teaching and missionary work under pagans in order to persuade people to believe in Jesus.

This propaganda motive means that Jesus is portrayed in the New Testament as in competition with the Greek gods and other miracle workers (see Funk and The Jesus Seminar 1998:547). The same propaganda motive also appears in Matthew's narrative of the silver coin in the mouth of the fish (Mt 17:24-27). It was an express purpose of Matthew, for instance, to proclaim the superiority of Jesus over the gods of the sea (see the narrative in Mt 17:24-27).

\section{Intrafamilial conflict}

What would the motive have been for people who followed the peasant Jesus? Many Jesus-followers began following him because he had healed them - he exorcised demons from them. It is unlikely that people would follow Jesus merely because he 'called' them. Davies (1995:81) considers intrafamilial conflict as one of the main causes of possession by devils. Those who had been healed by Jesus were not necessarily welcomed home again. The symptoms of their trauma had not necessarily disappeared.

Jesus encouraged people to avoid such a situation. He urged them to leave their families and become part of a surrogate (fictive) family with 'God as the father' (Gospel of Thomas 99; Mk 3:32-35; also supported by Sayings Source Q 9:59-62, 12:51-53, 14:26-27; Mk 10:28-30). That Jesus encouraged people to leave their families is to be understood in light of the circumstances that had caused the people to come to Jesus for healing and exorcism in the first place. Healing meant that they were acceptable before the God of Israel, the 'father' of Jesus.

The pronouncements of Jesus with regard to family should be understood in the context of people who had suffered rejection from their families for some reason or other. These people had an internal struggle.

Some of Jesus' pronouncements then make sense, for instance, in the Gospel of Thomas (68-69a): 'Jesus said: Congratulations to you when you are hated and persecuted ....' Jesus said: 'Congratulations to those who have been persecuted in their hearts: they are the ones who have truly come to know the Father' (see Scholar's Version, in Funk \& Hoover 1993:512; cf. Patterson 1998:33-75).

Elements of this Jesus tradition (persecution and marginalisation) also occur in the Sayings Source Q (see Lk 6:22-23). Matthew (5:11) interprets $Q$ in his context of synagogical controversy. In the context of the historical Jesus and Q (which is closer to Jesus than Matthew), 'persecution' (marginalisation) probably referred to familial problems that brought about internal torment. The following familiar sayings in the Gospel of Thomas and the Sayings Gospel Q form a pattern that indicates family disintegration:

Jesus says, '[Foxes have] their holes and birds have their nests. But the son of man has no place to lay his head down (and) to rest'. (Gospel of Thomas 86; cf. Q, 9:58)

Jesus says: 'Whoever does not hate his father and his mother cannot become a disciple of mine. And whoever does not hate his brothers and his sisters (and) will not take up his cross as I do, will not be worthy of me'. (Gospel of Thomas 55; cf. Q 14:26-27)

Jesus says: 'Blessed are the poor. For the kingdom of heaven belongs to you'. (Gospel of Thomas 54; cf. Q 6:20b)

Blessed are you who hunger, for you will be satisfied. (Q 6:2la; cf. Gospel of Thomas 69:2)

Blessed are you when they hate you (and) persecute you. (Gospel of Thomas 68; cf. Q 6:22)

Many of the Jesus-followers had been members of families where domestic conflict was experienced.

Now they were incorporated into a surrogate, a fictive family. Jesus 'healed' their situation. When Jesus encouraged people to 'hate' and leave their family, this was said to people who 
had already experienced serious familial conflict. Some of them already 'hated' their mothers, fathers, mothers-in-law and so forth. 'Family' in this context refers both to biological families and to marital relationships (Davies 1995:110). In Jesus, they found a new, fictive family.

Jesus probably sent out people on missions 'to heal and cast out devils in his name'. How effective they were would have depended on his reputation as a healer. At the time the name 'Jesus' was common. In itself, it would not have had a 'magical quality'. If Jesus had the reputation of a healer and exorcist, his representatives could heal and cast out demons on his behalf (Davies 1995:111).

Was Jesus a medical practitioner, that is, a 'doctor in antiquity' in the sense we described it? In other words, was Jesus interested in the curing of the biomedical causes of biological defects? 'No' - Jesus ought to be viewed as a faith healer. To follow Jesus would, in these terms, mean having faith in the power of the healer. Cases of faith healing are usually psychosomatic by nature. Davies (1995) is therefore of the opinion that a faith healer will only be effective when it comes to psychosomatic illness. Davies (1995:69-70) uses the term 'hidden illness', also known as 'hidden hysteria' and 'hidden neurosis' (nervous disease).

Capps (2008:xxii-xxiii) sees Jesus as a 'forerunner of the modern psychological profession' - see his book entitled Jesus the Village Psychiatrist (cf. Van Aarde 2010). Mental illness was known in antiquity (Capps 2008:10-11). Today, many of these disorders are classified as 'somatoform disorders' (DSM-IV, American Psychiatric Association 1994). The term 'hysteria' had previously been used in this regard. Sigmund Freud referred to such disorders as 'conversion disorders/hysteria' (Capps 2008:xxiv). According to Capps (2008:xx), Jesus 'shed his occupational role as carpenter in favor of the role of rural psychiatrist'. He not only taught his disciples how to heal, but also his own skills were more effective than the other 'physicians of his day' (Capps 2008:xiii-xiv). When Jesus performed 'miracles', he did not contradict natural laws; he simply had a deeper understanding of these laws because he connected mind and body (cf. Van Aarde 2010:1). His acts were performed 'at the tension points between village and city, family and parents and children and between siblings' (Capps 2008:xx). He was a 'psychiatrist' because he 'studied', 'treated' and 'prevented' disorders of the mind (Capps 2008:11-12).

A hidden illness can occur when a person develops guilt feelings about a particular action. The person attempts to deny the guilt, but in fact internalises it. Such internalised guilt manifests in 'self-punishment', such as blindness, paralysis or dermatitis (inflammation of the skin). Traumatic experiences can lead to 'hidden illness' if they are repressed, but later reappear in the form of physical symptoms. The main characteristic of such an illness is the change in or loss of physical function. This suggests physical sickness but is really expression of a psychological conflict or need. A patient could benefit from a hidden illness in two ways. A primary benefit, for instance, could be when inner conflict, which was the result of losing one's temper, manifests as 'dumbness'. Another example is when a person has witnessed a traumatic event and the inner conflict resulting from this is expressed as 'blindness'. In these cases, the symptom has symbolic value. It is a re-presentation of and specific solution to the underlying psychological conflict. Secondary benefit can be gained through avoidance of a particular activity that is harmful. For instance, a soldier whose arm is paralysed is unable to handle a weapon.

Somatic illness is a related syndrome. Characteristics include repeated and multiple somatic complaints that last for several years. Although medical help is sought, it is to no avail because the cause is not physical sickness. Somatic illness has hidden or pseudo-neurological symptoms. These include weight loss, dumbness, deafness, blindness, paralysis, muscle deterioration and excessive menstrual bleeding.

Somatic illness is, in essence, a form of hidden illness that occurs over a longer period of time. Dumbness, deafness, paralysis (complete or partial) and excessive menstrual bleeding constitute the majority of cases healed by Jesus. This leads Davies (1995:67-73) to conclude that Jesus probably healed people who suffered from these kinds of illnesses.

Different people react differently to stressful situations. Some students, for instance, develop a skin rash before a big examination (psychosomatic dermatitis), whereas others show no symptoms. In the same way, some 1st-century Palestinians 'survived' under the pressures of the Roman regime, whereas others became psychosomatically ill. Evidence shows that Jesus healed some of these. Those who have a greater tendency to exhibit somatic symptoms in the absence of physical sickness include (Depue \& Monroe 1986):

- persons with neuroticism or personality disorders that can be diagnosed

- persons with chronic psychopathological disorders, for instance, depressive disorders

- persons who experience continuous difficulties in their lives, for instance, a long period of unemployment, marital conflict or unsafe living space

- persons who experience an acute episode of stress-related psychological symptomatology, for instance, mourning after the death of a loved one. (p. 36)

The following conditions in the texts are examples of hidden disorders which were understood by 1st-century Mediterranean people as devil possession (Davies 1995):

- fever (Lk 4:38-39)

- loss of the movement of a limb (Mk 2:1-12)

- hunch back (Lk 13:10-12)

- blindness (Mk 8:22-27)

- deafness (Mk 7:31-37)

- blindness and deafness caused by a demon (Mt 12:22) and

- demonic possession (Mk 1:21-28). (p. 73) 
In these paradigms, somatic, sensory and identity dissociations are explained in terms of the belief in the existence of demons and demon possession. It is unclear whether diseases or defects were always understood as having been caused by a demon. It is clear, however, that all forms of defect could be understood in this way. The difference is that in New Testament times they had a 'realistic' image of the situation, namely, that the problems originated as a result of forces from the outside (demons).

In New Testament times, stress may have been caused by various factors. Class conflict which has its origin in economic exploitation was one such factor. Others include labelling and 'colonial dominance' (for a reflection on the relation between psychosomatic stress and external forces that influenced people, see Bourguignon 1976:53-54; Kiev 1964:135-137, 204-205, 262-263; Lewis 1971:35). Firstcentury peasants had 'deep feelings of uncertainty and alienation' (De Villiers 1986:27). This conditioned people psychologically and created fertile ground for miracle healings. Some 1st-century Palestinians managed to 'cope' with the pressures of the Roman regime and the Judaic tax levies.

Others became psychosomatically ill (see Davies 1995:2).

In the discussion of the exorcism story about 'Legion from Gerasa', the negative impact of Roman imperialism on the lives of the people was shown. Healing as a coping mechanism in the Jesus tradition was explained. Palestine under Herod was seen as the property of the Roman authorities (ager publicus populi Romani), which could be exploited (Oakman 1986:67). Exploitation and the expropriation of land were the cruel reality of the people in spite of a measure of self-governance granted to the Jerusalem temple authorities by the Roman Senate. Large sections of land were bought and rented out for personal gain or to support the Roman army (see Fiensy 1991:79). The lives of people who lived under such colonial domination and oppression were stressful. It follows therefore that mental disturbance, referred to as demonic possession, was part of the experience of communities. Many scholars (see Davies 1993:2; Hollenbach 1981:572580) showed the link between oppression and demonic possession. The classic example to illustrate this is Mark 5:1-20 (the possessed 'wild man' of Gerasa). By casting out the evil spirits, sending them into the pigs and letting them fall into the sea, Jesus not only illustrated his power over 'colonialism' but simultaneously destroyed the Roman legions' source of food. Roman imperialism meant that, on a social level, Israelites were possessed by demons. By casting out the demons Jesus (symbolically) liberated people from oppression (Crossan 1996:93). Each Israelite liberation fighter dreamed of the day that the Romans would be driven into the Mediterranean. In this pericope, we also see the convoluted nature of the Mediterranean social structure. The demonic possession of the man is the result of Roman oppression (politics). As a result of his possession, the man lives among the tombs and not with his family (familial structure). His demon possession also causes an upheaval in his family life.

A matter related to 'labelling' is the 'preservation of social power'. According to Bourguignon (1976:53), allegations of mental disturbance, demonic possession and magic could be used by dominant classes as a measure of social control. The allegations are a distancing technique which aims to discredit, isolate, deny common bonds and, eventually, to establish a separate identity. It could happen, for instance, when individuals questioned the authorities. These leaders would then classify the person as possessed by demons. In this way, they would gain social control over the person while simultaneously protecting and maintaining their own position in the social structure.

Demonic possession can also be seen as a socially acceptable form of indirect protest against dominance or even as an escape from such dominance (Fanon 1963:290; Kiev 1964:218-219; Lewis 1971:72; Ward \& Beaubrun 1980:206). Certain cases of demonic possession could be seen as a survival mechanism (see Davies 1995:37). It could be used, for instance, by children against their parents, or by women against their husbands. In this indirect way, feelings and demands that would otherwise not have been said could be expressed. Certain types of demonic possession could therefore be understood as a symptom of social conflict. In a stressful situation, demonic possession was a socially acceptable and recognised survival mechanism, which served as an outlet for the stress caused by circumstances (Davies 1995:81). According to Davies (1995:81), this is probably the reason why demonic possession usually occurs among women and children. In particular cultures, they are the subordinate ones in family structures. Possession by the devil, therefore, was often a coping mechanism, a way of responding, rather than a supernatural occurrence per se (Davies 1995:86).

In this sense, healers as 'agents of God' comply with what Augustine had in mind when he used the term Christus medicus. Jesus healings has become a 'model for Christian healing' (Pellegrino 1999:70-78). In the humanities the relevance of this notion Christus medicus extends focus areas such as the history of medicine as well as 'pastoral-medical' and depth-psychological aspects (see Eijk 1999b:53-58). Gollwitzer (2019) describes the example of 'Jesus the physician of the poor' as follows:

Als 'Portalfigur einer helfenden und heilenden Beziehung' komme Jesus Christus, dem Artz der Armen und dem großen Wundertäter, auch in der Gegenwart eine zentrale Vedeutung zu: Die Grundstruktur der biblisch erschlossen Christusmedicus-Gestalt kann auch heute Motivation und Orientierung anbieten für ein notwendiges, bewustes und begründetes Ethos des Helfens und Heilens im christlichen Kontext.

(p. 246)

Pellegrono (1999:73) distinguishes between the concepts Christus medicus and Christus patiens. The latter refers 
metaphorically to Christ as 'the patient'. It alludes to Jesus 'who knew suffering'.

From this perspective, Christus medicus implies Jesus as a healer who 'healed as an act of love for the sufferer and out of compassion' (Pellegrino 1999:73). Christ 'transformed medicine' from 'an occupation to a vocation'. It challenges the 'commercialization and corporatization of all human services' (Pellegrino 1999:72). It queries present-day medical care as a 'commodity'. Physicians are not only 'providers', 'case managers' or 'investors'. Patients are not only 'consumers' or 'clients'. Pellegrino (1999:77) concludes that the dialectic Christus medicus - Christus patiens demands the protection, restoration and deepening of the human and humane qualities of healing.

\section{Acknowledgements Competing interests}

The author has declared that no competing interests exist.

\section{Author(s) contributions}

I declare that I am the sole author of this article.

\section{Ethical consideration}

This article followed all ethical standards for a research without direct contact with human or animal subjects.

\section{Funding information}

This research received no specific grant from any funding agency in the public, commercial or not-for-profit sectors.

\section{Data availability statement}

Data sharing is not applicable to this article as no new data were created or analysed in this study.

\section{Disclaimer}

The views and opinions expressed in this article are those of the author and do not necessarily reflect the official policy or position of any affiliated agency of the author.

\section{References}

Arbesmann, R., [1954] 2016, 'The concept of "Christus Medicus" in St. Augustine', Traditio 10, 1-28, https://doi.org/10.1017/S0362152900005845

Bartlett, E. \& Stempsey, W.E., 2005, Elisha Bartlett's philosophy of medicine, Classics of Medical Ethics 83, Springer Netherlands, Heidelberg.

Bohak, G., 2008, Ancient Jewish magic: A history, Cambridge University Press, Cambridge.

Borg, M.J., 2006, The life, teaching, and relevance of a religious revolutionary, HarperCollins Publishers, New York.

Bostock, J., 1855, 'Pliny the elder, The natural history', in Perseus at Tufts, retrieved 28 May 2015, viewed 27 February 2019, from http://data.perseus.org/citations/ urn:cts:latinLit:phi0978.phi001.perseus-eng1:1.dedication.

Bourguignon, E., 1976, Possession, Chandler and Sharp, San Francisco, CA.

Burnham, J.C., 1999, 'A brief history of medical practitioners and professional historians as writers of medical history, Health and History 1(4), 250-273. https:// doi.org/10.2307/40111358
Callagher, E.V., 1982, Divine man or magician? Celsus and Origen on Jesus, Scholars, Chico, CA.

Capps, D., 2008, Jesus the village psychiatrist, Westminster John Knox Press, Louisville, CT.

Carter, W., 2015, 'Cross-gendered Romans and Mark's Jesus: Legion enters the pigs (Mark 5:1-20)', Journal of Biblical Literature 134(1), 139-155.

Cook, W.J., 2013, 'The Ebionites: Eccentric or essential early Christians?', Journal of Arts and Humanities 2(7), 15-21.

Craffert, P.F., 2008, The life of a Galilean shaman: Jesus of Nazareth in anthropologicalhistorical perspective, Wipf and Stock, Eugene, OR.

Craik, E.M., 2014, The 'Hippocratic' corpus: Content and context, Routledge, London.

Crossan, J.D., 1996, Who is Jesus? Answers to your questions about the historical Jesus, Harper Collins Publishers, New York.

Crossan, J.D., 1999, The birth of Christianity: Discovering what happened in the years immediately after the execution of Jesus, Harper Collins Publishers, New York.

Davies, S., 1993, 'Whom Jesus healed and how', The Fourth R 6(2), 1-11.

Davies, S., 1995, Jesus the healer, SCM Press, London.

Depue, R.A. \& Monroe, S.M., 1986, 'Conceptualisation and measurement of human disorder in life stress research: The problem of chronic disturbance', Psychological Bulletin 99, 36-51. https://doi.org/10.1037//0033-2909.99.1.36

De Villiers, P.G.R., 1986, 'Jesus and the divine man tradition: Miracles in the world and time of the New Testament', in P.G.R. De Villiers (ed.), Healing in the name of God, pp. 21-33, CB Powell Bible Centre, University of South Africa, Pretoria.

Drabkin, I.E., 1951, 'Soranus and his system of medicine', Bulletin of the History of Medicine 25(6), 503-518.

Dube, Z., 2018a, 'The Talmud, the Hippocratic Corpus and Mark's healing Jesus on infectious diseases', HTS Theological Studies 74(1), 4985. https://doi.org/10.4102/ hts.v74i1.4985

Dube, Z., 2018b, 'Models and perspectives concerning the identity of Jesus as healer', HTS Theological Studies 74(1), 4925. https://doi.org/10.4102/hts.v74i1.4925

Duling, D.C., 1999, 'Matthew 18:15-17: Conflict, confrontation, and conflict resolution in a "fictive kin" association', Biblical Theology Bulletin 29, 4-22. https://doi. org/10.1177/014610799902900102

Eijk, W.J., 1999a, Ancient histories of medicine: Essays in medical doxography and historiography in classical antiquity, Brill, Leiden.

Eijk W.J., 1999b, 'Carrying on the healing mission of Christ: Medical ethics in the Christian tradition', in H.A. Van Alphen (ed.), Neurosurgery and medical ethics, Acta Neurochirurgica Supplements 74, pp. 53-58, Springer, Vienna.

Fanon, F., 1963, The wretched of the earth, Ballantine, New York.

Farley, B.W., 2007, Jesus as man, myth, and metaphor: Beyond the Jesus of history debate, Wipf and Stock Publishers, Eugene, OR.

Fiensy, D.A., 1991, The social history of Palestine in the Herodian period, Studies in the Bible and early Christianity 20, Edwin Mellen, Lewiston, NY.

Funk, R.W., 1996, Honest to Jesus: Jesus for a new millennium, Harper Collins Publishing, New York.

Funk, R.W. \& Hoover, R.W. (and the Jesus Seminar), 1993, The five gospels: The search for the authentic words of Jesus, Macmillan Publishing Company, New York.

Funk, R.W. (\& The Jesus Seminar), 1998, The acts of Jesus: What did Jesus really do? The search for the authentic deeds of Jesus, A Polebridge Book, Harper, San Francisco, CA.

Garner, R.S., 2011, 'Annotated bibliography of works by John Miles Foley', Oral Tradition 26(2), 677-724. https://doi.org/10.1353/ort.2011.0031

Gleason, M.W., 2001, 'Mutilated messengers: Body language in Josephus', in S. Goldhill (ed.), Being Greek under Rome: Cultural identity, the Second Sophistic and the development of Empire, pp. 50-85, Cambridge University Press, Cambridge.

Goldsworthy, A., 2003, The complete Roman army, Thames \& Hudson, London.

Gollwitzer-Voll, W., [2007] 2019, Christus Medicus: Heilung als Mysterium Interpretationen eines alten Christusnamens und dessen Bedeutung in der Praktischen Theologie, Verlag Ferdinand Schöningh, Paderborn, Taschenbuch (e-book published by Brill Publishing, Leiden).

Gollwitzer-Voll, W., 2019, Interpretationen eines alten Christusnamens und dessen Bedeutung in der Praktischen Theologie, Brill, Leiden.

Hellerman, J.H., 2001, The ancient church as family, Fortress Press, Minneapolis, MN.

Hollenbach, P., 1981, 'Jesus, demoniacs, and public authorities: A socio-historical study', Journal of the American Academy of Religion 49, 572-580.

Horne, J., 2004, 'Masculinity in politics and war in the age of the nation-state', in S. Dudink, K. Hagemann \& J. Tosh (eds.), Masculinities in politics and war: Gendering modern history, pp. 23-30, Manchester University Press, Manchester.

Horrell, D.G., 2000, 'Early Jewish Christianity', in P.F. Esler (ed.), The early Christian world, Volume I-II, pp. 136-167, Routledge, London.

Jackson, R., 1988, Doctors and diseases in the Roman Empire, British Museum Press, London.

Jouanna, J., 2012, 'The legacy of the Hippocratic treatise the nature of man: The theory of the four humours', in J. Jouanna (ed.), Greek medicine from Hippocrates to Galen: Selected papers, transl. N. Allies and ed., with preface P. van der Eijk, pp. 335-360, Brill, Leiden.

Kahn, C.H., 2001, Pythagoras and the Pythagoreans: A brief history, Hackett Publishing Company, Indianapolis, IN.

Kiev, A. (ed.), 1964, Magic, faith and healing: Studies in primitive psychiatry today, Free Press, New York. 
Kirk, A., 2016, Q in Matthew: Ancient media, memory, and early scribal transmission of the Jesus tradition, The Library of New Testament Studies 564, Bloomsbury of the Jesus tradition,
Publishing, London.

Leander, H., 2013, Discourses of Empire: The Gospel of Mark from a postcolonial perspective Semeia 71, Society of Biblical Literature, Atlanta, GA.

Legrand, L., 2000, The Bible on culture: Belonging or dissenting, Orbis Books, Maryknol, NY.

Lewis, I.M., 1971, Ecstatic religion: An anthropological study of possession and shamanism, Penguin, Baltimore, MD.,

Malina, B.J. \& Rohrbaugh, R.L., 1992, Social science commentary on the synoptic gospels, Fortress, Minneapolis, MN.

McGrath, A.E., Christian theology: An introduction, John Wiley \& Sons, Chichester.

Moore, S.D., 2006, “"My name is Legion, for we are many": Representing Empire in Mark', in Moore, S.D. (ed.), Empire and apocalypse: Postcolonialism and the New Testament, Bible in the Modern World 12, pp. 24-44, Sheffield Phoenix, Sheffield.

Moxnes, H., 2011, Jesus and the rise of nationalism: A new quest for the nineteenth century historical Jesus, I.B. Tauris, New York.

Oakman, D.E., 1986, Jesus and the economic questions of his day, The Edwin Mellen Press, New York.

Patterson, S.J., 1998, 'Understanding the Gospel of Thomas today', in S.J. Patterson, J.M. Robinson \& H.-G. Bethge (eds.), The Fifth Gospel: The Gospel of Thomas comes of age, pp. 33-75, Trinity Press International, Harrisburg, PA.

Pellegrino, E.D., 1999, 'Christ, physician and patient: The model for Christian healing', The Linacre Quarterly 66(3), 70-78. https://doi.org/10.1080/20508549.1999. 11877550

Pilch, J.J.,1988, 'Understanding biblical healing: Selecting the appropriate model, Biblical Theology Bulletin 18, 60-66. https://doi.org/10.1177/014610798801800204
Pilch, J.J., 1995, 'Insights and models from medical anthropology for understanding the healing activity of the historical Jesus', HTS Theological Studies 51(2), 314-337. https://doi.org/10.4102/hts.v51i2.1385

Pormann, P.E., 2008, 'Paulos of Aigina', in P.T. Keyser \& G.L. Irby-Massie (eds.), Encyclopaedia of ancient natural scientists: The Greek tradition and its many heirs, p. 629, Routledge, London

Roukema, R., 1998, Gnosis \& geloof in het vroege Christendom, Uitgverij Meinema, Zoetermeer.

Smith, M., 1978, Jesus the magician, Harper \& Row, New York.

Todman, D., 2008. 'Soranus of Ephesus (AD 98-138) and the Methodist sect', Journa of Medical Biography 16(1), 51. https://doi.org/10.1258/jmb.2007.007011

Van Aarde, A.G., 2010, 'Understanding Jesus healings: Shrinking history and Donald Capps's different thinking cap', HTS Theological Studies 66(1), Art. \#821, 5 pages. https://doi.org/10.4102/hts.v66i1.821

Van Aarde, A.G., 2018, 'Reading the Christ hymn in Philippians in light of Paul's letter to the Romans', Neotestamentica 52(2), 359-375. https://doi.org/10.1353/neo. 2018.0022

Vermes, G., 1973, Jesus the Jew: A historian's reading of the gospels, William Collins Sons, London.

Ward, C. \& Beaubrun, M.H., 1980, 'The psychodynamics of demon possession', Journal for the Scientific Study of Religion 19(2), 201-207. https://doi.org/10.2307/ 1386254

Walsh, R., 2007, The world of shamanism: New views of an ancient tradition, Llewellyn Publications, Woodbury, MN.

Whalley, J.I., 1982, Pliny the elder, Historia naturalis, Sidgwick \& Jackson, London.

Yapijakis, C., 2009, 'Hippocrates of Kos, the father of clinical medicine', In Vivo 23(4), 507-514. 